\title{
Potential for nitrogen fixation and nitrification in the granite-hosted subsurface at Henderson Mine, CO
}

\section{Elizabeth D. Swanner ${ }^{*+}$ and Alexis S. Templeton}

Department of Geological Sciences, University of Colorado, Boulder, CO, USA

\section{Edited by:}

Andreas Teske, University of North

Carolina at Chapel Hill, USA

\section{Reviewed by:}

Barbara J. Campbell, University of

Delaware, USA

Tim Magnuson, Idaho State

University, USA

Christine M. Foreman, Montana State

University, USA

*Correspondence:

Elizabeth D. Swanner, Department of Geological Sciences, University of

Colorado, Campus Box 399, Boulder, CO 80309, USA.

e-mail: swanner@colorado.edu

${ }^{\dagger}$ Present address:

Elizabeth D. Swanner, Center for Applied Geoscience (ZAG),

EberhardKarls University Tübingen, Sigwartstrasse 10, 72076 Tübingen, Germany.
The existence of life in the deep terrestrial subsurface is established, yet few studies have investigated the origin of nitrogen that supports deep life. Previously, 16S rRNA gene surveys cataloged a diverse microbial community in subsurface fluids draining from boreholes 3000 feet deep at Henderson Mine, CO, USA (Sahl et al., 2008). The prior characterization of the fluid chemistry and microbial community forms the basis for the further investigation here of the source of $\mathrm{NH}_{4}{ }^{+}$. The reported fluid chemistry included $\mathrm{N}_{2}, \mathrm{NH}_{4}{ }^{+}(5-112 \mu \mathrm{M})$, $\mathrm{NO}_{2}{ }^{-}(27-48 \mu \mathrm{M})$, and $\mathrm{NO}_{3}{ }^{-}(17-72 \mu \mathrm{M})$. In this study, the correlation between low $\mathrm{NH}_{4}{ }^{+}$ concentrations in dominantly meteoric fluids and higher $\mathrm{NH}_{4}{ }^{+}$in rock-reacted fluids is used to hypothesize that $\mathrm{NH}_{4}{ }^{+}$is sourced from $\mathrm{NH}_{4}{ }^{+}$-bearing biotite. However, biotite samples from the host rocks and ore-body minerals were analyzed by Fourier transform infrared (FTIR) microscopy and none-contained $\mathrm{NH}_{4}{ }^{+}$. However, the nitrogenase-encoding gene nifH was successfully amplified from DNA of the fluid sample with high $\mathrm{NH}_{4}{ }^{+}$, suggesting that subsurface microbes have the capability to fix $\mathrm{N}_{2}$. If so, unregulated nitrogen fixation may account for the relatively high $\mathrm{NH}_{4}{ }^{+}$concentrations in the fluids. Additionally, the amo $A$ and $n \times r B$ genes for archaeal ammonium monooxygenase and nitrite oxidoreductase, respectively, were amplified from the high $\mathrm{NH}_{4}{ }^{+}$fluid DNA, while bacterial amoA genes were not. Putative nitrifying organisms are closely related to ammonium-oxidizing Crenarchaeota and nitrite-oxidizing Nitrospira detected in other subsurface sites based upon 16S rRNA sequence analysis. Thermodynamic calculations underscore the importance of $\mathrm{NH}_{4}{ }^{+}$ as an energy source in a subsurface nitrification pathway. These results suggest that the subsurface microbial community at Henderson is adapted to the low nutrient and energy environment by their capability of fixing nitrogen, and that fixed nitrogen may support subsurface biomass via nitrification.

Keywords: subsurface, nitrogen fixation, archaeal ammonia oxidation, nitrite oxidation, Crenarchaeota, Nitrospira

\section{INTRODUCTION}

At depths of at least $3.2 \mathrm{~km}$, an abundant and diverse microbial biosphere in habits terrestrial hard rock settings (Pedersen, 1997; Moser et al., 2003; Kovacik et al., 2006; Sahl et al., 2008), but the rock type is likely to exert tremendous control over the geochemically available nutrients and energy sources. In the basaltic-hosted subsurface settings, organisms may be sustained by $\mathrm{H}_{2}$ generated from reactions between water and Fe-rich mafic minerals (Stevens and Mckinley, 1995; Lin et al., 2006b). Organisms living in metamorphosed Precambrian sediments likely utilize $\mathrm{H}_{2}$ and $\mathrm{SO}_{4}{ }^{2-}$ derived from the reaction of decaying radionuclides with water and sulfide minerals in a process known as radiolysis (Lin et al., 2005, 2006b; Lefticariu et al., 2010). In sedimentary rock, organisms may be energetically supported by organic carbon associated with the deposits (Fredrickson et al., 1997; Kovacik et al., 2006). While most studies have focused on determining the energy sources supporting life in the terrestrial subsurface (see Lovley and Chapelle, 1995; Pedersen, 2000; Amend and Teske, 2005; Fredrickson and Balkwill, 2006 for reviews), the origins of nutrients to subsurface microbial communities have been insufficiently investigated. While field and laboratory experiments have implicated microbes in the release of species such as $\mathrm{Ca}, \mathrm{Si}, \mathrm{P}$, and Fe from minerals (Rogers et al., 1998; Edwards et al., 2003; Rogers and Bennett, 2004; Wu et al., 2008, 2009; Shelbolina et al., 2010), whether or not geologically sourced nitrogen (i.e., as ammonium substituted into potassic rocks) supports subsurface life is a question that has not yet been posed.

Many forms of nitrogen can be utilized biologically both for biosynthesis and energy metabolism. In subsurface settings, $\mathrm{N}_{2}$ may be sourced from the mantle (i.e., Crossey et al., 2009). Where oxidized nitrogen is absent, ammonium formed in the subsurface may be the most important form of nitrogen sustaining subsurface communities, but the origin of subsurface ammonium supporting microbial communities is unknown. However, at least two processes are possible. Although few nitrogen-bearing minerals are known, the substitution of $\mathrm{NH}_{4}{ }^{+}$for $\mathrm{K}^{+}$in silicate minerals is a widespread process (Holloway and Dahlgren, 2002). Granites, for instance, contain on average $\sim 45 \mathrm{ppm}$ ammonium (Hall, 1999). Another source of ammonium to subsurface environments is biological fixation of subsurface $\mathrm{N}_{2}$. However, the reduction of $\mathrm{N}_{2}$ to $\mathrm{NH}_{4}{ }^{+}$by the nitrogenase enzyme requires input of ATP at a high energetic cost (Broda and Paschek, 1980) that may inhibit this 
process under oligotrophic and anoxic conditions vs. photosynthetically supported surface environments (Lovley and Chapelle, 1995). Despite this, ammonium has been detected in numerous subsurface settings (Lin et al., 2006a; Onstott et al., 2006; Sahl et al., 2008).

Where ammonium is present in the subsurface, it may play a critical role not just as a nutrient, but as an energy source that sustains nitrifying subsurface microbial organisms. Functional gene studies have been used in characterizing nitrification in other subsurface sites where ammonia-oxidizing bacteria (AOB) and/or ammonia-oxidizing archaea (AOA) and nitrite-oxidizing bacteria (NOB; Proteobacteria or Nitrospira) are present (Hirayama et al., 2005; Spear et al., 2007; Weidler et al., 2007). Both archaeal amoA genes and AOA have been detected and commonly exceed the AOB and bacterial amoA genes in a number of oligotrophic settings, indicating that AOA may be adapted to low substrate niches (Martens-Habbena et al., 2009). Nitrite oxidation has also been recognized as a potentially important microbially mediated process in the deep subsurface (Hirayama et al., 2005; Gihring et al., 2006), specifically by the Nitrospira genus of bacteria. Nitrospira appear to be the most diverse and abundant NOB in nitrifying environments, thriving in nitrite and oxygen concentrations are too low to support proteobacterial NOB (Daims et al., 2001, 2006).

This study evaluates the origin of ammonium in fluids circulating through a granite-hosted molybdenum ore-body at $>3000$ foot depth. The fluids contain $\mathrm{N}_{2}, \mathrm{~N}_{2} \mathrm{O}, \mathrm{NO}_{3}{ }^{-}, \mathrm{NO}_{2}{ }^{-}$, and ammonium and an estimated $10^{3}-10^{4}$ cells $\mathrm{ml}$ (Sahl et al., 2008), and thermodynamically favorable nitrification reactions may be important in supporting the biomass detected in the fluids (Swanner, 2011). To evaluate possible geologic sources of ammonium, subsurface biotites, and muscovites were screened with Fourier transform infrared (FTIR) microscopy for the presence of $\mathrm{NH}_{4}{ }^{+}$. Concurrently, the potential for the microbial community to fix $\mathrm{N}_{2}$ into $\mathrm{NH}_{4}{ }^{+}$was assessed based on the presence of genes for nitrogen fixation in DNA from $\mathrm{NH}_{4}{ }^{+}$-bearing borehole fluids. The DNA was also used to evaluate whether genes for ammoniumand nitrite-oxidation were present. The current work builds on the prior study of Sahl et al. (2008), which reported the presence of archaea and Nitrospira in 16S rRNA clone libraries of the borehole fluids. The new mineralogical, functional gene, and phylogenetic analyses yield insight into the source of ammonium to the subsurface, and how the ecology of the subsurface microbial community may be influenced by the presence of ammonium as an energy source in the oligotrophic granite-hosted environment.

\section{MATERIALS AND METHODS SAMPLE COLLECTION AND PROCESSING}

Fluid samples were collected for geochemistry and molecular biology from boreholes draining at the 7025-foot level (elevation above sea level) within Henderson Mine during sampling trips in March 2006. The collection and processing of these samples has already been reported in Sahl et al. (2008). Samples were taken both before and after expandable packers were inserted to exclude $\mathrm{O}_{2}$ present in the mine tunnel air from equilibrating with draining fluids. Samples of the borehole fluids are named according to the level within the mine they were collected (e.g., 7025), whether they were collected from boreholes before or after insertion of packing devices ("D" for drain, "P" for packer) and the assigned number of each borehole on that level $(1,2,3$, etc.). Additional geochemical data for borehole 7025-D3 reported here was analyzed according to the methodology described in Sahl et al. (2008).

Mineral samples for $\mathrm{NH}_{4}{ }^{+}$analysis (biotites and muscovites) in this study were collected from surface sites surrounding the mine, and from a drill core (Table 1). The surface samples were collected from outcrops of Proterozoic biotite gneiss and migmatite (metasediments) intruded by the $1.4 \mathrm{Ga}$ Silver Plume granite within a 10-mile radius of Henderson Mine (Theobald, 1965). Subsurface samples from the ore-bearing stocks, the intruding

Table 1 | Potassic minerals for FTIR analysis.

\begin{tabular}{|c|c|c|c|c|c|}
\hline Sample name & Sample type & Location & Mineral & {$\left[\mathrm{NH}_{4}{ }^{+}\right] \mathrm{ppm}$} & Reference \\
\hline \multicolumn{6}{|l|}{ STANDARD } \\
\hline MS-14 & Pelitic and banded schists & Moine succession, Scotland & Biotite & 845 & Boyd and Philippot (1998) \\
\hline \multicolumn{6}{|l|}{ SAMPLE } \\
\hline SP1009 & Biotite gneiss and migmatite ${ }^{a}$ & Vasquez Creek Road, CO & Biotite & ND & This study \\
\hline HS-82-14 & Henderson Urad porphyry & Henderson underground & Biotite & ND & Stein (1985) \\
\hline HS-82-42 & Henderson Urad porphyry & Henderson underground & Biotite & ND & Stein (1985) \\
\hline HS-82-43 & Henderson porphyry & Henderson underground & Biotite & ND & Stein (1985) \\
\hline HS-82-59 & Henderson Urad porphyry & Henderson drill core & Biotite & ND & Stein (1985) \\
\hline HS-82-60 & Henderson primos interior & Henderson drill core & Biotite & ND & Stein (1985) \\
\hline HS-82-61 & Henderson seriate granite & Henderson drill core & Biotite & ND & Stein (1985) \\
\hline HS-82-62 & Henderson Dailey stock & Henderson drill core & Biotite & ND & Stein (1985) \\
\hline HS-82-15 & Henderson, silver plume granite & Henderson underground & Biotite & ND & Stein (1985) \\
\hline HS-82-53 & Silver plume granite, type locality & Silver plume, CO quarry & Biotite & ND & Stein (1985) \\
\hline $1225 \mathrm{~m}$ & Henderson granite & DUSEL drill core & Muscovite & ND & Jung et al. (2007) \\
\hline $1900 \mathrm{~m}$ & Henderson granite & DUSEL drill core & Muscovite & ND & Jung et al. (2007) \\
\hline
\end{tabular}

aTheobald (1965); ND= not detected. 
Henderson, Seriate, and Urad granite and the Silver Plume granite were acquired from Holly Stein at Colorado State University (Stein, 1985). Hydrothermally altered Henderson Granite was also acquired from a drill core, and named according to the depth of drilling in feet (Sahl et al., 2008). Samples were crushed, sieved between 100 and $400 \mu \mathrm{m}$ and biotites were concentrated with a Frantz magnetic separator. Minerals were washed in distilled $\mathrm{H}_{2} \mathrm{O}$ and dried at $50^{\circ} \mathrm{C}$ prior to analysis.

\section{FTIR MICROSCOPY}

Analysis for $\mathrm{NH}_{4}{ }^{+}$in biotites and muscovites was made by FTIR microscopy as previously described (Busigny et al., 2003, 2004; Papineau et al., 2005; Papineau, 2006). Briefly, individual grains were analyzed using a Thermo Nicolet Continuum microscope linked to a Nexus 670 FTIR spectrometer at the University of Colorado on $\mathrm{NaCl}$ plates under $\mathrm{CO}_{2}$-purged air. The infrared beam was collimated to a $100 \mu \mathrm{m} \times 100 \mu \mathrm{m}$ window and focused normal to the $c$-axis of mica grains. Two hundred transmission IR $(4000-650 \mathrm{~cm})$ spectra were collected per grain using an MCT/A detector cooled by liquid nitrogen to minimize electronic noise and absorption of water.

\section{AMPLIFICATION OF FUNCTIONAL GENES}

The DNA used in this study was originally acquired through DNA extraction and amplification procedures reported in Sahl et al. (2008). The DNA was tested here for the presence of functional genes of the nitrogen cycle by PCR amplification, cloning, and sequencing. To evaluate the potential for ammonium to be biologically fixed in the boreholes, the nifH gene that encodes for part of the nitrogenase enzyme was amplified from DNA of the 7025-P4 borehole using a nested PCR approach with primer sets nifA/nifRev and nifB/nifRev, respectively (Reed et al., 2010). The nifH products were extracted and cleaned from a gel using the EZNA gel extraction kit (Omega Bio-Tek, Inc.). The products were then cloned using a TOPO 1-shot cloning kit (Invitrogen) and sequenced commercially with M13F by SeqWright (Houston, TX, USA).

In addition to the $\mathrm{N}$-fixation genes, two marker genes for nitrification were also assessed by PCR amplification. The primers 301F/302R (Norton et al., 2002) were used to amplify the bacterial ammonium-oxidation gene $(a m o A)$ that encodes for part of the ammonium monooxygenase enzyme under previously described cycling conditions (Hirayama et al., 2005). The potential presence of archaeal amoA genes was also assessed with previously described primers (Francis et al., 2005; Spear et al., 2007). Finally, the presence of nitrite oxidation genes from the Nitrospira genus was interrogated with the nxrBF916 and nxrBR1237 primers designed to target a $321 \mathrm{bp}$ fragment of the $n \times r B$ gene that encodes for the $\beta$ subunit of the nitrite oxidoreductase enzyme (Lücker et al., 2010). This gene was previously called nor $B$, which is also the notation for nitric oxide reductase, and so was recently changed to $n x r B$ to eliminate confusion (Starkenburg et al., 2006). As the $n x r B$ gene is related to genes from the nar family that encodes for nitrate reductase in phylogenetically diverse organisms, it was necessary to use primers specific to the nitrite oxidoreductase-encoding genes from the Nitrospira genus. Only one definitive Nitrospira $n \times r B$ gene sequence exists in the public database from the metagenome of
Ca. Nitrospira defluvii (Lücker et al., 2010), and so the primers for that organism were used here. Successfully amplified genes were cloned and sequenced as described above for nifH. Representative functional gene sequences from this study have been submitted to GenBank under accession numbers JN560700-JN560714.

\section{PHYLOGENETIC ANALYSIS OF FUNCTIONAL GENES}

Nucleotide sequences were edited with Sequencher 4.7. Nucleotide sequences of the functional genes nifH and $n \times r B$ were translated to protein (amino acid) sequences using the transAlign script (Bininda-Emonds, 2005). Both nucleotide and amino acid sequences of functional genes were aligned using ClustalW. Similar sequences were identified from a blastn or blastx search of the NCBI database, and reference sequences were subsequently downloaded from this database. Phylogenetic trees were assembled using the RAxMLBlackBox with the JTT model of substitution (Stamatakis et al., 2008). The maximum-likelihood search was used to find the best-scoring tree, which was selected and edited in FigTree (http://tree.bio.ed.ac.uk/software/figtree/). Additionally, 16S rRNA sequences of Nitrospira from borehole 7025-P4 reported in Sahl et al. (2008) were reanalyzed in order to resolve the genus-level groupings of these organisms. The sequences were aligned using the Greengenes database (Desantis et al., 2006) and RAxMLBlackBox was used for tree construction.

\section{RESULTS \\ GEOCHEMISTRY OF THE FLUIDS}

The aqueous geochemistry of fluids from boreholes 7025-D1/P1, 7025-D4/P4, 7150-D1, and 7150-D3 were previously reported (Sahl et al., 2008). Geochemistry from an additional borehole, 7025-D3, are reported here to establish that $\mathrm{NH}_{4}{ }^{+}$increases corresponding to Mn along at least three boreholes (Figure 1). Borehole 7025-D3 had a pH of 6.14 and contained $0.52 \mathrm{mM} \mathrm{Mn}, 4.2 \mathrm{mM}$ $\mathrm{SO}_{4}{ }^{2-}, 0.68 \mathrm{mM} \mathrm{F}$, and $3 \mu \mathrm{M} \mathrm{NH}_{4}{ }^{+}$.

\section{$\mathrm{NH}_{4}+$ CONTENT OF MICAS}

Biotite samples analyzed for $\mathrm{NH}_{4}{ }^{+}$content (Table 1) were collected from surface outcrops of biotite gneiss and migmatite (sample SP1009) surrounding Henderson Mine. Biotites were also analyzed from subsurface samples of the Henderson and Seriate granite, the mineralized stocks of the Henderson and Urad ore-bodies, and the Silver Plume granite (sample names beginning with HS82). Muscovite grains from hydrothermally altered Henderson granite obtained from drill core were also analyzed (samples 1225 and $1900 \mathrm{~m}$ ). Although reference biotites from the Moine metasediment (MS-14; Boyd and Philippot, 1998) were successfully analyzed as $\mathrm{NH}_{4}{ }^{+}$-bearing standards with a characteristic and quantitative peak for $\mathrm{NH}_{4}{ }^{+}$bending at $1429 \mathrm{~cm}$ under FTIR (data not shown), none of the Henderson subsurface biotite or muscovite samples displayed a peak corresponding to $\mathrm{NH}_{4}{ }^{+}$bending.

\section{AMPLIFICATION AND PHYLOGENETIC ANALYSIS OF FUNCTIONAL GENES OF THE NITROGEN CYCLE}

Genomic DNA samples from boreholes for which $16 \mathrm{~S}$ rRNA clone libraries had been assembled (7025-D1/P1 and 7025-P4; Sahl et al., 2008) were screened for the presence of functional genes of the nitrogen cycle. The nifH gene was successfully amplified only from 


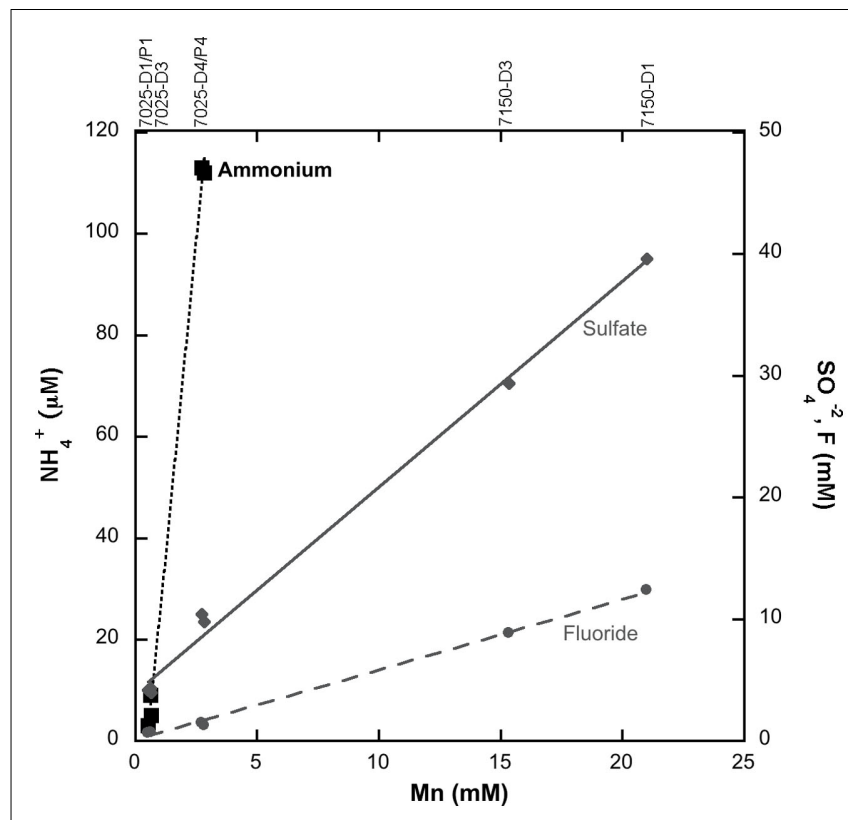

FIGURE 1 |The fluid chemistry of five boreholes from two levels within Henderson Mine demonstrate linear correlations between $\mathrm{Mn}$ and $\mathrm{F}^{-}$ or $\mathrm{SO}_{4}{ }^{2-}$ as recognized by Sahl et al. (2008), which is interpreted as mixing between a rock-reacted fluid and meteoric water. $\mathrm{NH}_{4}{ }^{+}$ concentrations for the boreholes 7025-D1/P1 and 7025-D1/P4 as reported by Sahl et al. (2008) and additional data from borehole 7025-D3 reported here suggest that ammonium may also source from water-rock reaction.

borehole 7025-P4 DNA. Cloning and sequencing of this product resulted in retrieval of 39 nifH sequences of $\sim 370 \mathrm{bp}$. The two unique nifH phylotypes (defined by $>90 \%$ amino acid identity) are shown in the phylogenetic tree in Figure 2, along with nifH from other environments, all of which are longer than $300 \mathrm{bp}$. One phylotype $(n=2)$ groups with Verrucomicrobia nifH sequences that encode the C-type nitrogenases characteristic of Clostridium, Gram positive bacteria, and $\delta$-Proteobacteria (Mehta et al., 2003; Young, 2005). However, there were no Verrucomicrobial 16S rRNA gene sequences detected in this sample. The Gram positive group includes the Paenibacillus that are known to fix nitrogen (Canfield et al., 2005), and Paenibacillus were isolated previously from Henderson Mine (Mayhew et al., 2008). No nifH sequences were amplified from the DNA of the Paenibacillus isolates with the nifH primers used in this study (data not shown), suggesting nifH may not be present in Henderson Mine Paenibacillus. The second phylotype $(n=37)$ clusters separately, near to nifH sequences from the Nitrospira phylum and encodes B-type nitrogenases (characteristic of Proteobacteria, Cyanobacteria, and Firmicutes; Young, 2005). The only members of the Nitrospirae phylum detected in 7025-P4 DNA sample were from the genus Nitrospira, and none of these organisms are known to contain nifH (Lücker et al., 2010).

The amoA gene for bacterial ammonia oxidation could not be amplified from either of the borehole samples. DNA from a Japanese Gold Mine that contained AOB (Hirayama et al., 2005) was used as a positive control to ensure that this was indeed a negative result and not due to a problem with the amplification protocol. In contrast, 43 archaeal ammonium-oxidation amoA gene sequences of $\sim 700$ bp were amplified from 7025-P4 DNA. Four unique phylotypes ( $>90 \%$ nucleotide identity) were recovered. The relationship of 7025-P4 amoA and other environmental and pure culture amoA are shown in Figure 3, where all of the sequences included in the analysis are longer than $500 \mathrm{bp}$. One phylotype groups together with sequences from a mine adit in Colorado and hot springs clones in China (Spear et al., 2007; Zhang et al., 2008; Jiang et al., 2010), while two other phylotypes fall into a previously described cluster of amoA (Beman and Francis, 2006), determined by a common node with high bootstrap values.

The $n x r B$ primers amplified several differently sized products, and as such are non-specific and should not be used in future amplification of $n x r B$ from environmental DNA. For this reason, and because none of the proteobaterial nitrifying organisms (i.e., Nitrobacter, Nitrococcus, and Nitrospina) were detected in 7025P1 DNA (Sahl et al., 2008), the $n x r B$ primers were only used on 7025-P4 DNA. Amplification of the $n x r B$ gene with Nitrospiraspecific primers was successful for the Nitrospira-containing DNA from borehole 7025-P4, retrieving two sequences of $\sim 339$ bp that are $93 \%$ identical in amino acid to the $n \times r B$ of Ca. Nitrospira defluvii (FP929003; Lücker et al., 2010). The 7025-P4 nxrB amino acid sequences were aligned with the $n \times r B$ from nitrite-oxidizing Proteobacteria, as well as with sequences of the related nar genes (encoding the nitrate reductase enzyme). All of the sequences included in the analysis were longer than $250 \mathrm{bp}$. The 7025-P4 $n \times r B$ cluster closely with the Ca. Nitrospira defluvii $n \times r B$, a relationship that is supported by high bootstrap values (Figure 4). This cluster is separated from the nar sequences and the $n \times r B$ sequences of Proteobacteria.

\section{DISCUSSION}

GEOLOGICAL CONTRIBUTIONS TO THE SUBSURFACE NITROGEN CYCLE The aqueous geochemistry of two of the borehole fluids at the 7025 level addressed in this study have been previously reported (Sahl et al., 2008). The ammonium concentrations of boreholes P1 and P4 were 5 and $112 \mu \mathrm{M}$, respectively 2 weeks after being fitted with packing devices, and the concentrations are very similar to those reported before packer insertion ( 9 and $113 \mu \mathrm{M}$, respectively). Sahl et al. (2008) noted geochemical trends from this dataset signifying the mixing of different fluids, a rock-reacted brine, and meteoric water, via the covariance in $\mathrm{F}_{\text {or }} \mathrm{SO}_{4}{ }^{2-}$ and the dissolved Mn concentration across fluids sampled from five boreholes at two levels within Henderson Mine. In this study we note that the fluid $\mathrm{NH}_{4}{ }^{+}$concentration also appears to increase corresponding with the greater degree of water-rock interaction across boreholes of the 7025 level, when data from a third borehole, 7025-D3 (reported here) is included (Figure 1). This trend suggests that $\mathrm{NH}_{4}{ }^{+}$is sourced from the breakdown of $\mathrm{NH}_{4}{ }^{+}$-bearing minerals at depth. From the mineral assemblage present at Henderson (Theobald, 1965; Stein, 1985), the phases most likely to contain $\mathrm{NH}_{4}{ }^{+}$are biotite and muscovite, where $\mathrm{NH}_{4}{ }^{+}$can be substituted for $\mathrm{K}^{+}$ (Honma and Itihara, 1981; Hall, 1987).

Geological nitrogen as $\mathrm{NH}_{4}{ }^{+}$substituted for $\mathrm{K}^{+}$could not be detected in biotite collected from Precambrian metasedimentary rocks surrounding Henderson Mine. Thus it is unlikely that the Henderson granite or stocks would have taken up $\mathrm{NH}_{4}{ }^{+}$directly 


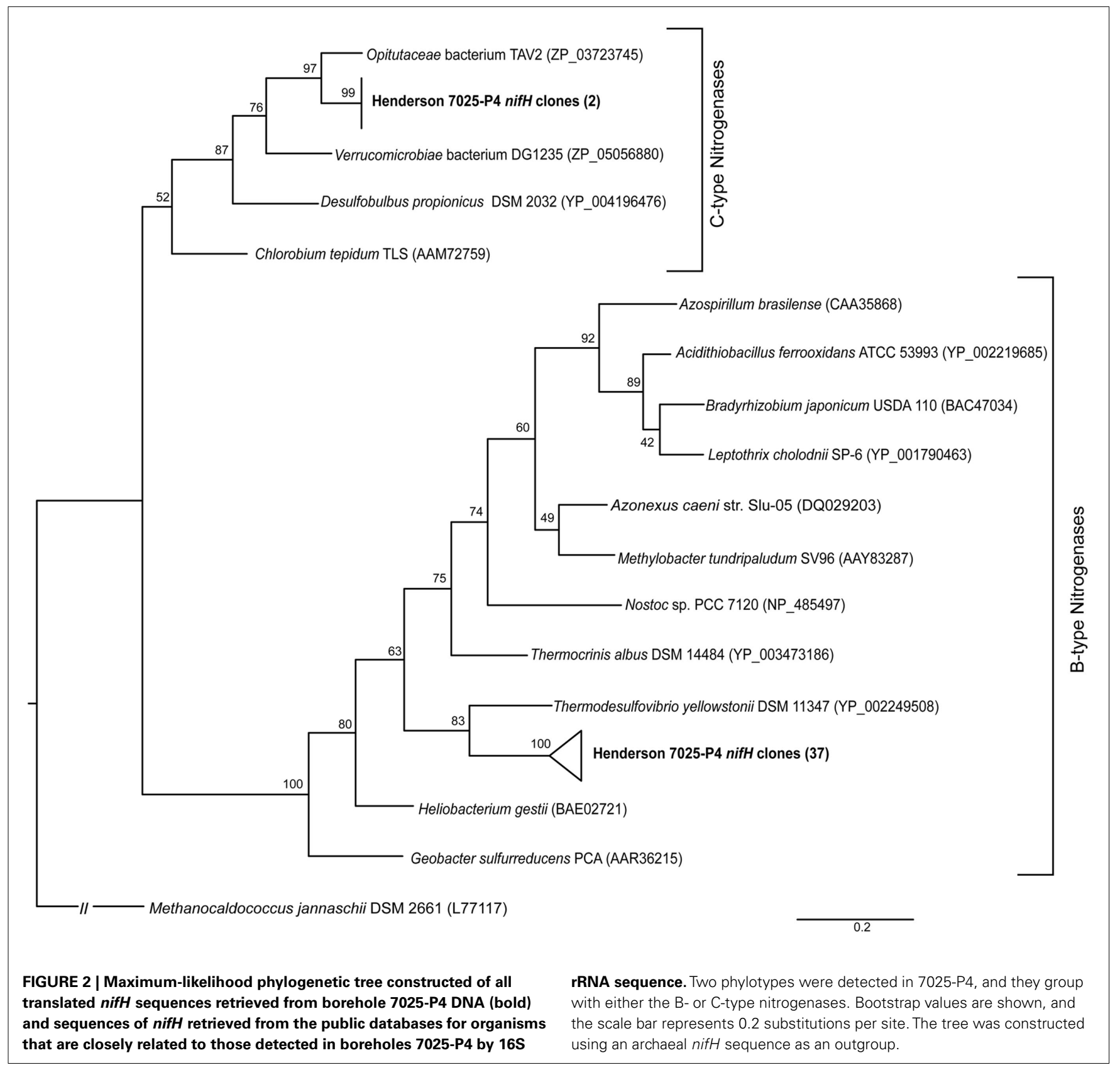

from the metasediments when they were emplaced (i.e., Hall et al., 1991). However, the Tertiary Henderson granite and ore-bearing stocks (e.g., variably containing molybdenite, quartz, K-feldspar, biotite, fluorite, pyrite, or magnetite) are not directly hosted by the metasediments, but rather by the Precambrian Silver Plume granite. For this reason, biotites from the Silver Plume granite were also screened for the presence of ammonium. The Silver Plume granite biotites also do not show evidence of $\mathrm{NH}_{4}{ }^{+}$incorporation. Even if Silver Plume granite did contain ammonium, it is unlikely to have been transferred to the Henderson granite and ore-bearing stocks, because previous isotopic studies indicate little chemical interaction between the Henderson ore-body and surrounding wall rocks (Stein and Hannah, 1985).

Another possible mechanism that could supply ammonium to biotites of the Tertiary Henderson granite and the ore-bearing stocks would be from interaction with the Proterozoic basement, if it contains $\mathrm{NH}_{4}{ }^{+}$(Honma and Itihara, 1981; Hall, 1988). This type of transfer is possible based on the $\varepsilon_{\mathrm{Nd}}$ and $\varepsilon_{\mathrm{Sr}}$ values of Henderson granite, which sources its Mo from the mid- to lower crust (Farmer and Depaolo, 1984). Although an appropriate mid- or lower-crust sample was not available for FTIR analysis to screen for $\mathrm{NH}_{4}{ }^{+}$-content, none of the biotites of the Henderson granite and stocks contained $\mathrm{NH}_{4}{ }^{+}$. While other potassic phases were not analyzed (i.e., muscovite and potassium feldspar), biotites generally have the highest $\mathrm{NH}_{4}{ }^{+}$contents of silicate minerals (Honma and Itihara, 1981; Hall, 1987). However, muscovites that formed 


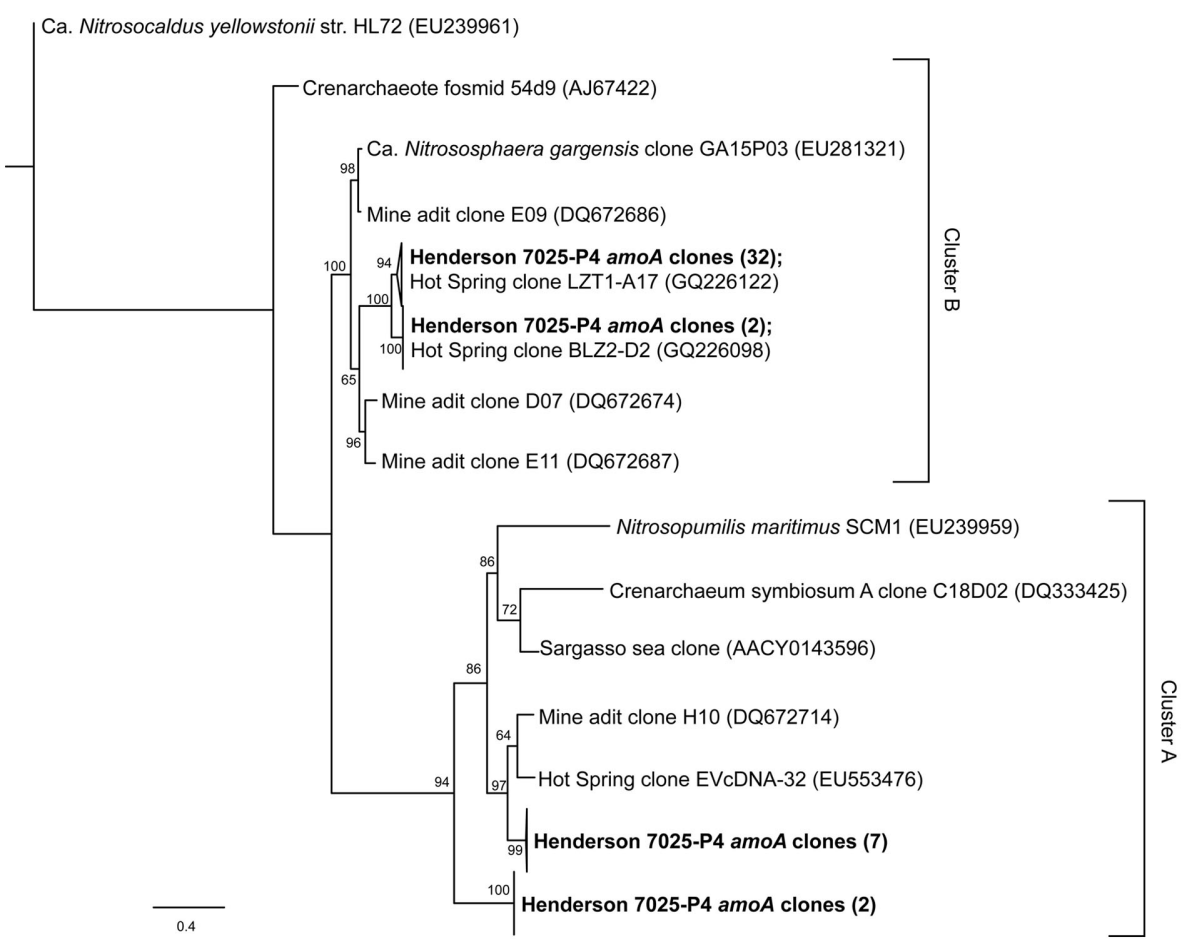

FIGURE 3 | Schematic representation of the best-scoring maximum-likelihood tree generated by an alignment of nucleotide sequences corresponding to the archaeal amoA genes amplified from this study (bold) and other environments and pure cultures. The phylotypes from this study fall into four distinct sub-clusters within the previously defined A and B clusters (Beman and Francis, 2006; Zhang et al., 2008). The bacterial amoA outgroup has been removed for visual clarity. The scale represents 0.4 substitutions per site.

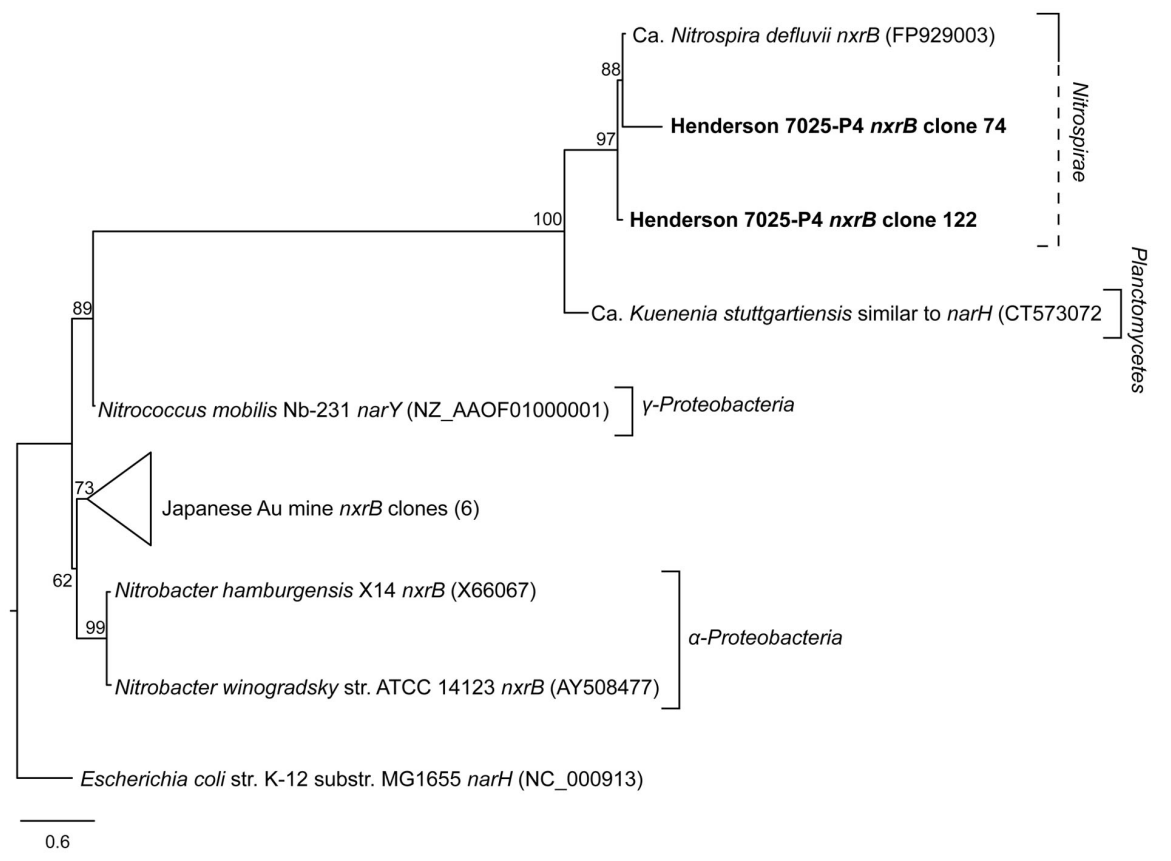

FIGURE 4 | Best-scoring maximum-likelihood phylogenetic analysis of amino acid sequences for $\boldsymbol{n x r} B$ and related nar genes. The Henderson $n \times r B$ amino acid sequences retrieved in this study, clones 74 and 122 (bold) are highly similar to the sequence of $n \times r B$ in $\mathrm{Ca}$. Nitrospira defluvii, and this relationship is supported by high bootstrap values. The other $n \times r B$ sequences belong to organisms of the Proteobacteria, except for the Japanese Au mine clones (Hirayama et al., 2005), whose phylogenetic affiliation is unknown. Scale bar represents 0.6 substitutions per site. 
after hydrothermal alteration of the Henderson granite were analyzed for $\mathrm{NH}_{4}{ }^{+}$because hydrothermal alteration of granites with fluids that have interacted with $\mathrm{NH}_{4}{ }^{+}$-bearing crustal rocks has been observed for intrusive granites in Italy (Hall et al., 1991). The hydrothermal muscovites did not contain $\mathrm{NH}_{4}{ }^{+}$, which is consistent with the geological interpretation that the suite of hydrothermally altered minerals at Henderson formed due to the introduction of juvenile, magmatic fluids that that did not interact with the surrounding metasediments, granite, or groundwater (Seedorff and Einaudi, 2004).

There are other potential sources of non-biological $\mathrm{NH}_{4}{ }^{+}$that could not be evaluated for several reasons. For example, nitrogen compounds could have been introduced to subsurface fluids through ammonium nitrate fuel oil (ANFO) that was used as a blasting agent at Henderson (Jensen et al., 1983). However, the boreholes had flushed for almost a year prior to sampling and only the rock-reacted fluids being dewatered from the mine contained high $\mathrm{NH}_{4}{ }^{+}$(i.e., borehole 7025-P4; $112 \mu \mathrm{M}$ ). A meteoric source was unlikely as well, as the most dilute, meteoric-dominated waters contained the lowest levels of $\mathrm{N}$ (as $\mathrm{NH}_{4}{ }^{+}, \mathrm{NO}_{2}{ }^{-}$, and $\mathrm{NO}_{3}{ }^{-}$; Figure 1). Modern precipitation in Colorado can exhibit high levels of nitrate (up to $\sim 20 \mu \mathrm{M}$ ) in the mountains from industrial activities (Faure and Mensing, 2005) that could be transported to the subsurface in meteoric water. However, the dilute borehole waters at Henderson have an average residence time of 13,000 years based on ${ }^{14} \mathrm{C}$ dating, and is dominantly pre-1950s based on tritium content (Sahl et al., 2008), further underscoring that this modern meteoric water is not likely to be the nitrogen source to subsurface fluids.

\section{BIOLOGICAL FIXATION AS A SOURCE OF SUBSURFACE AMMONIUM}

The presence of $n$ if $H$ genes in DNA in borehole 7025-P4 (Figure 2; $112 \mathrm{\mu M} \mathrm{NH}_{4}{ }^{+}$), and the lack of detectable nifH genes in boreholes 7025-D1/P1 (5-9 $\left.\mu \mathrm{M} \mathrm{NH}_{4}{ }^{+}\right)$suggests that microbes inhabiting 7025-P4 fluids are capable of fixing $\mathrm{N}_{2}$ gas to $\mathrm{NH}_{4}{ }^{+}$. This finding of a biological source of nitrogen specific to 7025-P4 is consistent with the lack of evidence for a general subsurface nitrogen source from the breakdown of $\mathrm{NH}_{4}{ }^{+}$-bearing potassic minerals (Table 1). However, the presence of functional genes does not necessarily signify expression or activity of the encoded enzymes, and so further experiments are needed to evaluate whether nitrogen fixation is occurring. Fresh samples would be needed to measure ${ }^{15} \mathrm{~N}$ uptake or acetylene reduction as evidence for nitrogen fixation, and we have been unable to access Henderson Mine for further sampling of these boreholes, and so the further geochemical assays could not be undertaken to augment the dataset in the current study.

If organisms in 7025-P4 fluids do fix nitrogen, they would need to be utilizing a metabolic reaction capable of generating enough ATP and electrons to fuel nitrogen fixation. Although specific $\mathrm{N}_{2}$ fixing organisms cannot be identified in 7025-P4 based solely on the detected 16S rRNA and nifH genes, the geochemical dataset of Sahl et al. (2008) can be used to infer which chemolithoautotrophic metabolisms could support the subsurface community thermodynamically. The reaction of $\mathrm{H}_{2} \mathrm{~S}$ oxidation with electron acceptors such as $\mathrm{O}_{2}, \mathrm{NO}_{3}{ }^{-}, \mathrm{Fe}(\mathrm{OH})_{3}$ and $\mathrm{MnO}_{2}$, or $\mathrm{S}^{0}$ and $\mathrm{Fe}^{2+}$ oxidation with $\mathrm{NO}_{2}{ }^{-}$, are more thermodynamically favorable in borehole 7025-P4 relative to 7025-P1(Swanner, 2011). There is a greater than $-10 \mathrm{~kJ} \mathrm{~mol}^{-1}$ of electrons transferred increase between 7025 P1 and 7025-P4 for all of these reactions, and all yield at least $-20 \mathrm{~kJ} \mathrm{~mol}^{-1}$ of electrons transferred in borehole 7025-P4. Thus nitrogen fixation may be fueled preferentially in the more rockreacted borehole fluid by any of these reactions. Given the fact that the borehole fluid microbial community compositions are modulated by the degree of mixing between meteoric and rock-reacted fluids (Sahl et al., 2008), we suggest that the potential for nitrogen fixation is strongly tied to the aqueous geochemistry. Furthermore, despite this energetic strain of nitrogen fixation, it has been documented for deep-sea sulfate-reducing methanotroph consortia, whose syntrophic metabolisms provides one of the lowest energetic yields known to sustain microbial life $\left(\sim 40 \mathrm{~kJ} \mathrm{~mol}^{-1}\right.$ electron transferred to support two organisms; Dekas et al., 2009), suggesting that the energetic yields of reactions possible in 7025-P4 fluids could support nitrogen fixation.

The inference that ammonium is biologically fixed in Henderson fluids raises another question about why nitrogen-fixing organisms would fix nitrogen to levels as high as $112 \mu \mathrm{M} \mathrm{NH}_{4}{ }^{+}$ in an environment where total numbers of microbes are only $10^{3}-10^{4}$ cells $\mathrm{ml}$, and only half of the nitrogen is converted into organic forms (Sahl et al., 2008). Intriguingly, nitrogen fixation occurs in deep-sea methane-oxidizing archaeal/bacteria consortia in sediments that already contain ammonium (Dekas et al., 2009), suggesting either that localized depletions of ammonium within the consortium drive fixation, or that nitrogenase activity is not well regulated by $\mathrm{NH}_{4}{ }^{+}$concentrations. A lack of regulation on $\mathrm{N}_{2}$-fixation by $\mathrm{NH}_{4}{ }^{+}$concentrations up to $94 \mathrm{mM}$ has been recently documented for the verrucomicrobial methanotroph Methylacidiphilum fumairiolicum strain SolV (Khadem et al., 2010), and some proteobacterial nitrogenases also appear to be unregulated by $\mathrm{NH}_{4}{ }^{+}$(Rudnick et al., 1997). One other reason for nitrogen fixation in the presence of abundant ammonium may be that the transfer of ammonium between nitrogenfixing and ammonium-utilizing microbes may not be very efficient. Nitrogen-fixing cyanobacteria from the Baltic Sea have been observed to lose up to $30 \%$ of their fixed nitrogen to bulk surroundings (Ploug et al., 2010). Further culture and assay-based studies are needed to determine if and why excess nitrogen is being fixed in 7025-P4, but such experiments were not undertaken in the current work due to the sampling limitations discussed above.

It is well established that nif $H$ tree topology often mirrors topology of the 16S rRNA gene tree (with some variation due to lateral gene transfer; Hennecke et al., 1985; Normand and Bouquet, 1989; Young, 2005). Although not definitive evidence of phylogenetic affiliation, the nifH sequences detected in borehole 7025-P4 DNA may be useful in informing the classes of potential nitrogen-fixing organisms. In Figure 2 the C-type nifH phylotype $(n=2)$ groups with Verrucomicrobia nifH, but no 16S rRNA from Verrucomicrobia were detected in the DNA of 7025-P4. This phylotype of nifH may source from the Chlorobi in 7025-P4 DNA, which are phylogenetically close to Verrucomicrobia by $16 \mathrm{~S}$ rRNA and nifH measures. Chlorobi $16 \mathrm{~S}$ rRNA genes were detected in this sample (Sahl et al., 2008), although the Henderson nifH and Chlorobi nifH protein sequences were only $91 \%$ similar. A more likely possibility is that this nif operon was horizontally transferred (Hirsch et al., 1995) and may not reflect the true phylogeny of organisms. 
The B-type nifH phylotype $(n=37)$ was much more abundant than the C-type phylotype in 7025-P4 DNA, implying the organisms from which these sequences came from must be much more abundant in the sample. In fact, the most dominant organism in this sample by the measure of $16 \mathrm{~S}$ rRNA gene sequences $(37 \%)$ are the novel phylum Henderson candidate division that were first detected in the Henderson environment (Sahl et al., 2008), and subsequently detected in seafloor basalt (Omoregie et al., 2008; Santelli et al., 2008). The phylogenetic analysis of Sahl et al. (2008) demonstrate that the closest related phyla to Henderson candidate division are the Acidobacteria and the Nitrospirae. In Figure 2, the B-type nifH phylotype is similarly related to the Nitrospirae sequence from T. yellowstonii. There were Nitrospirae 16S rRNA sequences detected in this sample (Sahl et al., 2008), but they belong specifically to the Nitrospira genus, whose only representative sequenced genome does not contain any homologs to the nifH gene, suggesting this genus is unlikely to fix nitrogen (Lücker et al., 2010). There were also Acidobacteria 16S rRNA sequences detected in the 7025-P4 DNA sample, but of the three sequenced Acidobacteria genomes, none possess any nif genes (Ward et al., 2009). The B-type nifH phylotype may source from Henderson candidate division bacteria, but this phylotype of nifH was not amplified from the DNA of borehole 7025-P1, which contained $56 \%$ Henderson candidate division 16 S rRNA sequences. Without further investigation of the genome of Henderson candidate division or other organisms in borehole 7025-P4, it is unclear which organisms the B-type or C-type nifH phylotype source from.

\section{HENDERSON FLUIDS SUPPORT NITRIFICATION}

The presence of high $\mathrm{NH}_{4}{ }^{+}, \mathrm{NO}_{2}{ }^{-}$, and $\mathrm{NO}_{3}{ }^{-}$and low levels of $\mathrm{O}_{2}(1.25 \mu \mathrm{M})$ in borehole 7025 -P4 suggest that ammonium and nitrite oxidation may be occurring. In fact, both of the reactions of nitrification, summarized by Eq. 1 and 2 below, are thermodynamically favorable in borehole 7025-P4 (Swanner, 2011).

$\mathrm{NH}_{4}^{+}+1.5 \mathrm{O}_{2} \rightarrow \mathrm{NO}_{2}^{-}+\mathrm{H}_{2} \mathrm{O}+2 \mathrm{H}^{+}$

$\mathrm{NO}_{2}^{-}+0.5 \mathrm{O}_{2} \rightarrow \mathrm{NO}_{3}^{-}$

Reactions 1 and 2 yield -40 and $-35 \mathrm{~kJ}$ mol electron transferred, respectively. In addition, micromolar quantities of gaseous $\mathrm{N}_{2} \mathrm{O}$ were detected in 7025-P4. $\mathrm{N}_{2} \mathrm{O}$ is an intermediate in both microbial nitrification/denitrification, and as such is a hallmark of biological nitrogen cycling. One abiotic mechanism for $\mathrm{N}_{2} \mathrm{O}$ production involves reaction of $\mathrm{NO}_{2}{ }^{-}$or $\mathrm{NO}_{3}{ }^{-}$with (ultra)mafic rocks and minerals (dolerite, augite, and olivine; Samarkin et al., 2010), but none of these phases are present at Henderson and so this mechanism is unlikely. $\mathrm{N}_{2} \mathrm{O}$ can also be produced from $\mathrm{NO}_{2}^{-}$ in the presence of $\mathrm{Fe}^{2+}$ and $\mathrm{Cu}^{2+}$ (both observed in the borehole fluids) within $24 \mathrm{~h}$ at pH 6 (Moraghan and Buresh, 1977). Therefore, even if $\mathrm{N}_{2} \mathrm{O}$ is abiotically produced, the additional presence of $\mathrm{NO}_{2}{ }^{-}$strongly implicates either nitrification or denitrification in 7025-P4 fluids as a mechanism for continued $\mathrm{NO}_{2}{ }^{-}$production. Because of the presence of $\mathrm{N}_{2} \mathrm{O}$, it is also worth noting that nitrate reduction coupled to inorganic electron donors is thermodynamically favorable; in contrast, microbially mediated reactions such as anammox, the anaerobic oxidation of ammonium with nitrite is less likely in Henderson, due to predicted unfavorable thermodynamics under insitu conditions (Swanner, 2011). In addition, no organisms belonging to the phylum Planctomycetes were detected at Henderson, and only these organisms are currently known to carry out anammox (Kuenen, 2008). A final consideration on the favorability of nitrification in the borehole fluids is that the $C: N$ is near unity, which should drive the consumption of ammonium by nitrification relative to the assimilation of ammonium by heterotrophs, because $C: N$ values generally need to be $>20$ for heterotrophic ammonium uptake to predominate (Strauss and Lambert, 2000). Additionally, inorganic phosphate levels were was below detection (Sahl et al., 2008), further suggesting that the borehole fluids are oligotrophic.

The organisms most likely to be carrying out ammoniumoxidation in borehole 7025-P4 are AOA, as no AOB were detected in 7025-P4 DNA by $16 \mathrm{~S}$ rRNA (Sahl et al., 2008). The archaeal organisms previously detected in borehole 7025-P4 belong to the phylum Crenarchaeota (Brochier-Armanet et al., 2008; Spang et al., 2010) as reported in Figure 6 of Sahl et al. (2008). Our re-alignment of these previously retrieved $16 \mathrm{~S}$ rRNA sequences with sequences from other subsurface mines (data not shown) reveal that they are closely related to other subsurface Crenarchaeota, some of which have been implicated in archaeal ammonium oxidation (Takai et al., 2001; Nunoura et al., 2005; Spear et al., 2007; Rastogi et al., 2010). Four of the six archaeal sequences retrieved from 7025-P4 are $97 \%$ identical to $C a$. Nitrososphaera gargensis, an ammoniumoxidizing (AOA) isolate (Hatzenpichler et al., 2008), and amoA genes have been detected and implicated in ammonium oxidation for other closely related organisms within the Crenarchaeota (Treusch et al., 2004). Our finding of amoA in DNA of the 7025-P4 borehole that contains high $\mathrm{NH}_{4}{ }^{+}$and organisms closely related to AOA suggests, in conjunction with the geochemical evidence for nitrification, that AOA may be active in subsurface fluids at Henderson Mine. Furthermore, this study is at least the third to amplify archaeal $a m o A$ from a terrestrial subsurface setting (Spear et al., 2007; Weidler et al., 2007), and our phylogenetic analysis in Figure 3 suggests that there may be sub-clusters of amoA defined by subsurface and hot spring clones (Beman and Francis, 2006; Zhang et al., 2008). Future subsurface studies may reveal further AOA and amoA diversity, and will establish the contribution of these processes at depth to the global nitrogen cycle.

The presence of archaeal amoA in the 7025-P4 DNA sample and absence of the bacterial version of this gene may be explained by the geochemical conditions. The sub-millimolar concentration of $\mathrm{NH}_{4}{ }^{+}$in borehole 7025-P4 is ideal for AOA who are inhibited by higher concentrations of $\mathrm{NH}_{4}{ }^{+}$(i.e., 2-3 mM). One cultivated AOA, Nitrosopumilus maritimus has an ammonia monooxygenase enzyme that reaches maximal activity at $\mathrm{NH}_{4}{ }^{+}$concentrations that are 100-fold less than those observed for AOB enzymes (MartensHabbena et al., 2009). The low- $\mathrm{O}_{2}$ concentrations in 7025-P4 may favor AOA who thrive when dissolved $\mathrm{O}_{2}$ is $3-20 \mu \mathrm{M}$ (Ergruder et al., 2009). The archaea were only detected after packer insertion, further supporting their adaptation to thrive in low- $\mathrm{O}_{2}$ niches. The presence of sulfide in wastewater reactors and estuary sediments has an inhibitory effect on the activity of $\mathrm{AOB}$ relative to AOA (Sears et al., 2004; Caffrey et al., 2007), and a similar phenomenon has been observed in cultivated AOB (Hooper and Terry, 
1973). Dissolved sulfide was not measured in Henderson fluids, but is likely present due to the extensive sulfide mineralization at Henderson, and the formation of elemental sulfur where borehole fluids are released into oxic mine tunnels (Templeton and Swanner, unpublished data).

While the Crenarchaeota have only recently been characterized as AOA (Könnecke et al., 2005), the ensuing widespread detection of AOA in soils, estuaries and marine environments and their abundance worldwide relative to AOB signifies that these organisms likely do account for a large portion of both terrestrial and marine nitrogen cycling (Francis et al., 2007). AOA are also preferentially found in low-nutrient environments (Ergruder et al., 2009), and they seem to be adapted to higher salinity (Bernhard et al., 2010), although AOB appear to outnumber AOA in estuarine environments regardless of varying nutrient fluxes (Wankel et al., 2011). AOA are also predominant in environments above $40^{\circ} \mathrm{C}$ (Zhao et al., 2011), which is the temperature of Henderson fluids. Furthermore, AOA are phylogenetically diverse, and this diversity may underscore their adaptation to diverse environmental conditions relative to the phylogenetically restricted AOB (Francis et al., 2005).

$\mathrm{AOB}$ and AOA are not the only organisms capable of oxidizing ammonia. Methanotrophs can also oxidize ammonia due to the broad substrate specificity of the enzyme methane monooxygenase. However, methanotrophs cannot grow using ammonia as a substrate, nor can ammonia oxidizers grow using methane as a substrate (Bédard and Knowles, 1989; Hanson and Hanson, 1996). Bacterial methanotrophs reside within the $\alpha$ - and $\gamma$-Proteobacteria. Both of these Proteobacterial divisions were detected in borehole 7025-P4 DNA via 16S rRNA, and the fluids from this sample contained submicromolar levels of methane (Sahl et al., 2008). However, the closest isolated methanotrophs were only $92 \%$ related to the $7025-\mathrm{P} 4 \alpha$-Proteobacteria sequence, and only $86 \%$ identical to the $\gamma$-Proteobacteria sequences. Although ammonium-oxidation by methanotrophs may not be significant in Henderson borehole fluids, it could be an important process in other sites were ammonium and methanotrophs are both abundant, such as a Japanese gold mine (Hirayama et al., 2005). Methanotrophs could contribute to subsurface nitrogen cycling by fixing nitrogen as well (Hanson and Hanson, 1996; Auman et al., 2001). The ability to fix nitrogen may confer a selective advantage for methanotrophs inhabiting low-nutrient subsurface habitats, as is hypothesized for a Japanese uranium mine (Mills et al., 2010).

The nitrification pathway may be carried to completion by the nitrite-oxidizing Nitrospira genus (Daims et al., 2001). 16S rRNA sequences belonging to the Nitrospira genus were detected in borehole 7025-P4 DNA (1\% of the microbial community; Sahl et al., 2008). As was the case with AOA, Nitrospira were not detected in the DNA of borehole 7025-D1/P1. The Nitrospira sequences from 7025-P4 are distinct at the phylum level from the Henderson candidate division proposed for unique sequences detected in DNA from both boreholes at the Henderson 7025 level (D1/P1 and P4; Sahl et al., 2008). In the current analysis in Figure 5, the Nitrospira sequences detected from 7025-P4 DNA group closely with a clone from a deep gold mine (Gihring et al., 2006), but apart from other identified clusters of Nitrospira (Daims et al., 2001; Lebedeva et al., 2011). The bootstrap values that support this topology are all $>90 \%$, suggesting that Henderson sequences may define a novel cluster of subsurface Nitrospira. All sequences included in this analysis were longer than $800 \mathrm{bp}$.

Despite the limited sequence data available for the Nitrospira nxrB gene, which encodes the nitrite oxidoreductase, the primers of Lücker et al. (2010) did successfully amplify $n \times r B$ from the DNA sample of 7025-P4. As 7025-P4 DNA did not contain any $16 \mathrm{~S}$ rRNA sequences corresponding to Proteobacterial nitrite-oxidizers (i.e., Nitrobacter, Nitrococcus, and Nitrospina), it is possible the $n x r B$ sequences we amplified are from Nitrospira spp. Because of the high similarity of the amino acid sequence of the amplified genes to that of the Ca. Nitrospira defluvii $n \times r B$ and the high bootstrap values supporting this relationship, it is likely 7025-P4 $n \times r B$ clones 74 and 122 are actual Nitrospira $n x r B$ sequences (Figure 4). Alternatively, this sequence could encode a related nar gene or a $n x r B$ gene from Proteobacteria, but this is unlikely as no nitrifying Proteobacteria were detected in this sample. However, without direct evidence from longer sequences of the Nitrospira genome in borehole 7025-P4 DNA, it cannot be established that the $n \times r B$ genes from this study belong to Nitrospira genus, and the sample limitations discussed above prohibit further genetic analysis. The $n x r B$ sequences retrieved in this study may be useful in future primer design and acquisition of quality environmental sequence data for Nitrospira, which will aid in understanding the evolutionary history of the enzymes involved in nitrite/nitrate oxidation and reduction and the organisms that possess them.

The presence of Nitrospira in borehole 7025-P4 offers insight into the ecology of these organisms. Three pure cultures consist of obligately lithotrophic nitrite-oxidizers from the genus Nitrospira (Watson et al., 1986; Ehrich et al., 1995; Lebedeva et al., 2008, 2011). The cultures were isolated out of both freshwater and marine habitats (Koops and Pommerening-Röser, 2001), as well as hot springs (Lebedeva et al., 2011), suggesting the ecology of this genus is not limited to one type of geochemical environment. The abundance of Nitrospira in nitrite-oxidizing environments in comparison to nitrite-oxidizers of the Proteobacterial nitriteoxidizers (i.e., Nitrobacter) is evidence for their contribution to nitrite oxidation in a number of environments (Daims et al., 2001). The Nitrospira genus seems to be inhibited by higher concentrations of nitrite (i.e., >5-15 mM; Ehrich et al., 1995; Lebedeva et al., 2011) and $\mathrm{O}_{2}$ (Altmann et al., 2003) than are preferred by Nitrobacter species (Ehrich et al., 1995; Daims et al., 2006), suggesting Nitrospira may be preferentially adapted to oligotrophic conditions such as are experienced in borehole 7025-P4. Nitrospira have now been detected in three subsurface settings where $\mathrm{O}_{2}$ was $<10 \mu \mathrm{M}$ and $\mathrm{NO}_{2}{ }^{-}$did not exceed $120 \mu \mathrm{M}$ (i.e., borehole 7025-P4; Hirayama et al., 2005; Weidler et al., 2007), although they have also been detected in subsurface fluids with millimolar concentrations of $\mathrm{NO}_{2}{ }^{-}$but low- $\mathrm{O}_{2}$ (Gihring et al., 2006). Nitrospira may well be quite common in subsurface settings that contain $\mathrm{NO}_{2}{ }^{-}$, and future investigations may uncover more phylogenetic and physiological knowledge about this important genus.

\section{CONCLUSION}

This study demonstrates that the deep subsurface microbial communities in the borehole fluids of Henderson Mine have the 


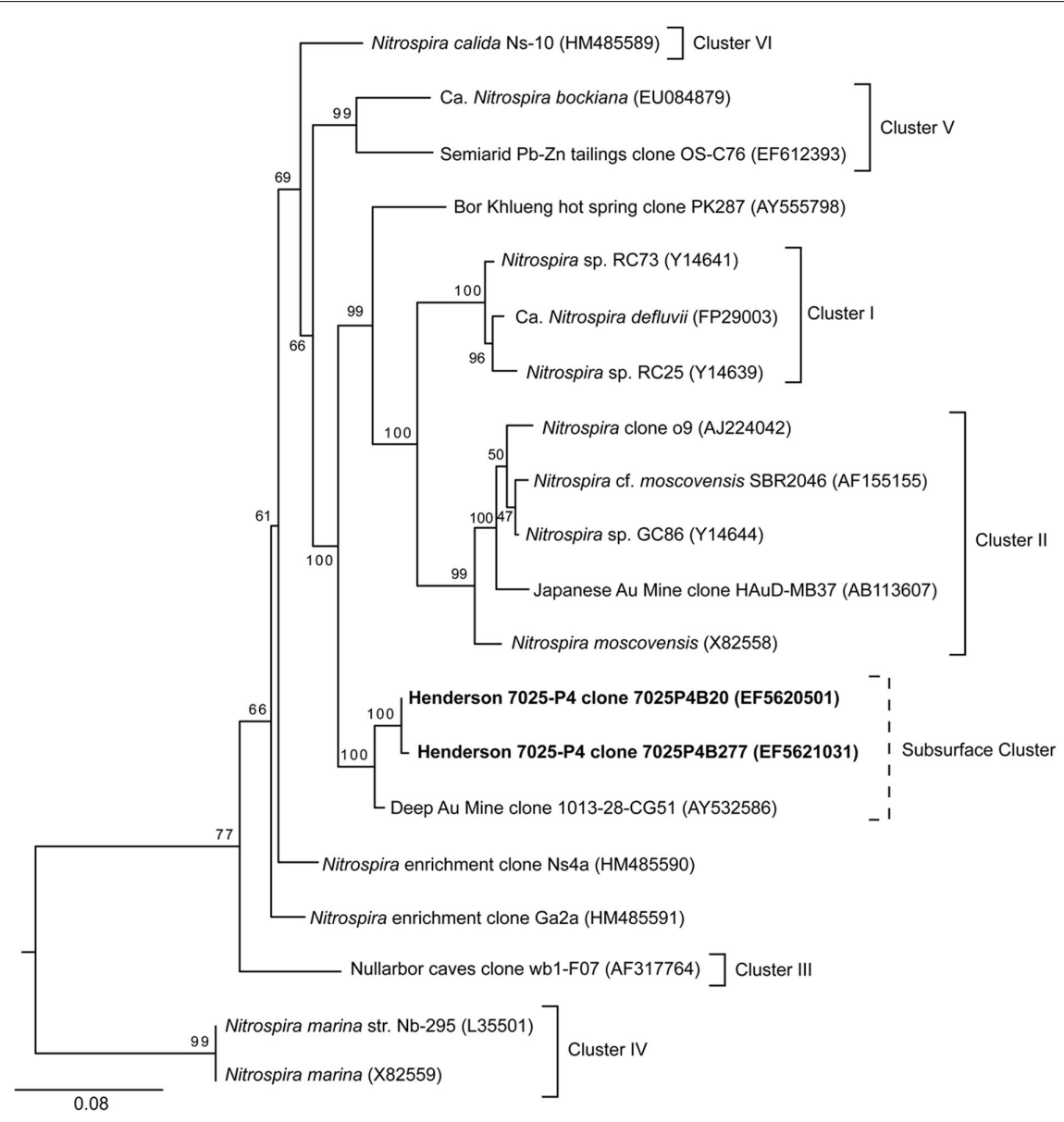

FIGURE 5 | Phylogenetic relationship of NOB in the Nitrospira genus as determined by an alignment of the 16S rRNA nucleotide sequences from borehole 7025-P4 (bold) reported in Sahl et al. (2008) and those from the literature. While the phylogenetic affiliation of these sequences in the Nitrospira phylum was established by Sahl et al. (2008), further analysis was undertaken here to resolve the position of these sequences within the Nitrospira genus. The relationships are represented by a best-scoring maximum-likelihood tree in which clusters I-VI are marked (after Daims et al., 2001; Lebedeva et al., 2011). The two sequences retrieved from Henderson Mine do not group in a known cluster, but bootstrap values support their association with a South African Au Mine clone, which may represent a new subsurface Nitrospira cluster. Bootstrap values are shown, and the scale bar represents 0.1 substitutions per site. The proteobacterial outgroup has been removed for clarity. genetic capacity to fix nitrogen. This fixed nitrogen, as ammonium, is likely to be the primary nitrogen source for organisms living in the subsurface, as no evidence was found that ammonium was sourced geologically from $\mathrm{NH}_{4}{ }^{+}$-bearing potassic minerals such as biotites. Although the presence of nifH genes in borehole 7025$\mathrm{P} 4$ is only indirect evidence that nitrogen fixation is occurring, it is also correlates to elevated $\mathrm{NH}_{4}{ }^{+}$concentrations and the lack of nifH in boreholes with lower $\mathrm{NH}_{4}{ }^{+}$concentrations. If nitrogen fixation is occurring at Henderson it highlights the phenomenon of excess nitrogen fixation under energy-poor conditions. The availability of ammonium, regardless of the ultimate source, also has important consequences for the subsurface microbial community not only as an essential nutrient but because it can also be used as an energy source. There is evidence for ammonium and nitrite oxidation in borehole 7025-P4 where ammonium concentrations are highest based on the detection of archaeal ammonia monooxygenase $(a m o A)$ and nitrite oxidoreductase $(n \times r B)$ functional genes. While other subsurface studies have detected genes encoding for both steps of nitrification (Hirayama et al., 2005; Weidler et al., 2007), neither study addressed the source of ammonium fueling this process. Moreover, the $n x r B$ sequences detected from borehole 7025-P4 are the first amplified from the Nitrospira genus in environmental samples. The presence of nitrifiers 3000 feet below the surface at Henderson also reinforces the idea that Crenarchaea and Nitrospira may be adapted to low nutrient and substrate environments and could be key players in nitrogen cycling in similar settings. Thus this also work highlights the potential that biological nitrogen fixation and nitrification may be ubiquitous biogeochemical processes in the deep subsurface and maybe important to consider in accounts of global nitrogen cycling.

\section{ACKNOWLEDGMENTS}

This work was supported by grants from the David and Lucille Packard Foundation and the National Science Foundation (NSFBIO 0623815) to Alexis S. Templeton. The investigation was also 
made possible by a Geological Society of America Graduate Student Research Grant to Elizabeth D. Swanner. We thank Henderson Mine and Robert Callaghan for previous access to borehole fluids, Jason Sahl, and John Spear for providing DNA samples for analysis, Hisako Hirayama for contributing a positive control for PCR,

\section{REFERENCES}

Altmann, D., Stief, P., Amann, R., De Beer, D., and Schramm, A. (2003). In situ distribution and activity of nitrifying bacteria in freshwater sediment. Environ. Microbiol. 5, 798-803.

Amend, J. P., and Teske, A. (2005). Expanding frontiers in deep subsurface microbiology. Palaeogeogr. Palaeoclimatol. Palaeoecol. 219, 131-155.

Auman, A. J., Speake, C. C., and Lidstrom, M. E. (2001). nifH Sequences and nitrogen fixation in type I and type II methanotrophs. Appl. Environ. Microbiol. 67, 4009-4016.

Bédard, C., and Knowles, R. (1989). Physiology, biochemistry and specific inhibitors of $\mathrm{CH}_{4}, \mathrm{NH}_{4}{ }^{+}$, and $\mathrm{CO}$ oxidation by methanotrophs and nitrifiers. Microbiol. Rev. 53, 68-84.

Beman, J. M., and Francis, C. A. (2006). Diversity of ammoniaoxidizing archaea and bacteria in the sediments of a hypernutrified subtropical estuary: Bahia del Tobari, Mexico. Appl. Environ. Microbiol. 72, 7767-7777.

Bernhard, A. E., Landry, Z. C., Blevins, A., De La Torre, J. R., Giblin, A. E., and Stahl, D. A. (2010). Abundance of ammonia-oxidizing archaea and bacteria along an estuarine salinity gradient in relation to potential nitrification rates. Appl. Environ. Microbiol. 76, 1285-1289.

Bininda-Emonds, O. R. P. (2005). TransAlign: using amino acids to facilitate the multiple alignment of protein-coding DNA sequences. BMC Bioinformatics 6, 156. doi:10.1186/1471-2105-6-156

Boyd, S. R., and Philippot, P. (1998). Precambrian ammonium biogeochemistry: a study of the Moine metasediments, Scotland. Chem. Geol. 144, 257-268.

Brochier-Armanet, C., Boussau, B., Gribaldo, S., and Forterre, P. (2008). Mesophilic crenarchaeota: proposal for a third archaeal phylum, the Thaumarchaeota. Nat. Rev. Microbiol. 6, 245-252.

Broda, E., and Paschek, G. A. (1980). Evolutionary considerations on the thermodyamics of nitrogen fixation. BioSystems 13, 47-56.

Busigny, V., Cartigny, P., Philippot, P., and Javoy, M. (2003). Ammonium quantification in muscovite by infrared spectroscopy. Chem. Geol. 198, 21-31.

Busigny, V., Cartigny, P., Philippot, P., and Javoy, M. (2004). Quantitative analysis of ammonium in biotite using infrared spectroscopy. Am. Mineral. 89, 1625-1630.

Caffrey, J. M., Bano, N., Kalanetra, K., and Hollibaugh, J. T. (2007). Ammonia oxidation and ammoniaoxidizing bacteria and archaea from estuaries with differing histories of hypoxia. ISME J. 1, 660-662.

Canfield, D. E., Thamdrup, B., and Kristensen, E. (2005). Aquatic Geomicrobiology. San Diego, CA: Elsevier Academic Press.

Crossey, L. J., Karlstrom, K. E., Springer, A. E., Newell, D., Hilton, D. R., and Fischer, T. (2009). Degassing of mantle-derived $\mathrm{CO}_{2}$ and $\mathrm{He}$ from springs in the southern Colorado Plateau region - Neotectonic connections and implications for groundwater systems. Geol. Soc. Am. Bull. 121, 1034-1053.

Daims, H., Maixner, F., Lücker, S., Stoecker, K., Hace, K., and Wagner, M. (2006). Ecophysiology and niche differentiation of Nitrospiralike bacteria, the key nitrite oxidizers in wastewater treatment plants. Water Sci. Technol. 54, 21-27.

Daims, H., Nielsen, J. L., Nielsen, P. H., Schleifer, K.-H., and Wagner, M. (2001). In situ characterization of nitrospira-like nitrite-oxidizing bacteria active in wastewater treatment plants. Appl. Environ. Microbiol. 67, 5273-5284.

Dekas, A. E., Poretsky, R. S., and Orphan, V. J. (2009). Deep-sea archaea fix and share nitrogen in methaneconsuming microbial consortia. Science 326, 422-426.

Desantis, T. Z. Jr., Hugenholtz, P., Keller, K., Brodie, E. L., Larsen, N., Piceno, Y. M., Phan, R., and Andersen, G. L. (2006). NAST: a multiple sequence alignment server for comparative analysis of 16S rRNA genes. Nucleic Acids Res. 34, W394-W399.

Edwards, K. J., Mccollom, T. M., Konishi, H., and Buseck, P. R. (2003). Seafloor bioalteration of sulfide minerals: results from in situ incubation studies. Geochim. Cosmochim. Acta 67, 2843-2856.

Ehrich, S., Behrens, D., Lebedeva, E., Ludwig, W., and Bock, E. (1995). A

and Holly Stein for sharing subsurface mineral samples described in Stein (1985). Katherine Wright engaged in helpful discussions, Terry Legg, Diana Nemergut, and Chuck Robertson provided assistance with phylogenetic analyses, and Steve Mojzsis and Nicole Cates assisted with sample collection.

new obligately chemolithoautotrophic, nitrite-oxidizing bacterium, Nitrospira moscoviensis sp. nov. and its phylogenetic relationship. Arch. Microbiol. 164, 16-23.

Ergruder, T. H., Boon, N., Wittebolle, L., Marzorati, M., and Verstraete, W. (2009). Environmental factors shaping the ecological niches of ammonia-oxidizing archaea. FEMS Microbiol. Rev. 33, 855-869.

Farmer, G. L., and Depaolo, D. J. (1984). Origin of mesozoic and tertiary granite in the Western United States and implications for pre-mesozoic crustal structure 2. Nd and Sr isotopic studies of unmineralized and $\mathrm{Cu}$ - and Mo-mineralized granite in the precambrian craton. J. Geophys. Res. 89, 10141-10160.

Faure, G., and Mensing, T. M. (2005). Isotopes: Principles and Application. Hoboken, NJ: John Wiley and Sons, Inc.

Francis, C. A., Beman, J. M., and Kuypers, M. M. M. (2007). New processes and players in the nitrogen cycle: the microbial ecology of anaerobic and archaeal ammonia oxidation. ISME J. 1, 19-27.

Francis, C. A., Roberts, K. J., Beman, J. M., Santoro, A. E., and Oakley, B. B. (2005). Ubiquity and diversity of ammonia-oxidizing archaea in water columns and sediments of the ocean. Proc. Natl. Acad. Sci. U.S.A. 102, 14683-14688.

Fredrickson, J. K., and Balkwill, D. L. (2006). Geomicrobial processes and biodiversity in the deep terrestrial subsurface. Geomicrobiol. J. 23, 345-356.

Fredrickson, J. K., Mckinley, J. P., Bjornstad, B. N., Long, P. E., Ringelberg, D. B., White, D. C., Krumholz, L. R., Suflita, J. M., Colwell, F. S., Lehman, R. M., Phelps, T. J., and Onstott, T. C. (1997). Pore-size constraints on the activity and survival of subsurface bacteria in a late cretaceous shalesandstone sequence, northwestern New Mexico. Geomicrobiol. J. 14, 183-202.

Gihring, T. M., Moser, D. P., Lin, L.H., Davidson, M., Onstott, T. C., Morgan, L., Milleson, M., Kieft, T. L., Trimarco, E., Balkwill, D. L., and Dollhopf, M. E. (2006). The distribution of microbial taxa in the subsurface water of the Kalahari Shield,
South Africa. Geomicrobiol. J. 23, 415-430.

Hall, A. (1987). The ammonium content of Caledonian granites. J. Geol. Soc. London 144, 671-674.

Hall, A. (1988). Crustal contamination of minette magmas: evidence from their ammonium contents. Neues $\mathrm{Jb}$. Miner. Monat. 3, 137-143.

Hall, A. (1999). Ammonium in granites and its petrogenetic significance. Earth Sci. Rev. 45, 145-165.

Hall, A., Bencini, A., and Poli, G. (1991). Magmatic and hydrothermal ammonium in granites of the Tuscan magmatic province, Italy. Geochim. Cosmochim. Acta 55, 3657-3664.

Hanson, R. S., and Hanson, T. E. (1996) Methanotrophic bacteria. Microbiol. Rev. 60, 439-471.

Hatzenpichler, R., Lebedeva, E., Spieck, E., Stoecker, K., Richter, A., Daims, H., and Wagner, M. (2008). A moderately thermophilic ammoniaoxidizing crenarchaeote from a hot spring. Proc. Natl. Acad. Sci. U.S.A. 105, 2134-2139.

Hennecke, H., Kaluza, K., Thöny, B., Fuhrmann, M., Ludwig, W., and Stackenbrandt, E. (1985). Concurrent evolution of nitrogenase gens and 16S rRNA in Rhizobium species and other nitrogen fixing bacteria. Arch. Microbiol. 142, 342-348.

Hirayama, H., Takai, K., Inagaki, F., Yamato, Y., Suzuki, M., Nealson, K. H., and Horikoshi, K. (2005). Bacterial community shift along a subsurface geothermal water stream in a Japanese gold mine. Extremophiles 9, 169-184.

Hirsch, A. M., Mckhann, H. I., Reddy, A., Liao, J., Fang, Y., and Marshall, C. R. (1995). Assessing horizontal transfer of nifHDK genes in eubacteria: nucleotide sequence of nifK from Frankia strain HFPCcI3. Mol. Biol. Evol. 12, 16-27.

Holloway, J. M., and Dahlgren, R. A. (2002). Nitrogen in rock: occurrences and biogeochemical implications. Global Biogeochem. Cycles 16, 1118.

Honma, H., and Itihara, Y. (1981). Distribution of ammonium in minerals of metamorphic and granitic rocks. Geochim. Cosmochim. Acta 45, 983-988. 
Hooper, A. B., and Terry, K. R. (1973). Specific inhibitors of ammonia oxidation in Nitrosomonas. J. Bacteriol. 115, 480-485.

Jensen, E. B., Doane, C. E., and Pirozzoli, J. F. (1983). Nonelectric explosives detonation at the Henderson mine. Min. Eng. 35, 1560-1563.

Jiang, H., Huang, Q., Dong, H., Wang, P., Wang, F., Li, W., and Zhang, C. (2010). RNA-based investigation of ammonia-oxidizing archaea in hot springs of Yunnan Province, China. Appl. Environ. Microbiol. 76, 4538-4541.

Jung, C. K., Claes, D. R., Kuchta, M., Wilson, R. J., and Zimmerman, E. D. (2007). Proposal for DUSEL at Henderson Mine. Henderson Mine, CO: National Science Foundation.

Khadem, A. F., Pol, A., Jetten, M. S. M., and Op Den Camp, H. J. M. (2010). Nitrogen fixation by the verrucomicrobial methanotroph 'Methylacidiphilum fumariolicum' SolV. Microbiology 156, 1052-1059.

Könnecke, M., Bernhard, A. E., De La Torre, J. R., Walker, C. B., Waterbury, J. B., and Stahl, D. A. (2005). Isolation of an autotrophic ammoniaoxidizing marine archaeon. Nature 437, 543-546.

Koops, H.-P., and Pommerening-Röser, A. (2001). Distribution and ecophysiology of the nitrifying bacteria emphasizing cultured species. FEMS Microbiol. Ecol. 37, 1-9.

Kovacik, Jr. W. P., Takai, K., Mormile, M. R., Mckinley, J. P., Brockman, F. J., Fredrickson, J. K., and Holben, W. E. (2006). Molecular analysis of deep subsurface Cretaceous rock indicates abundant Fe(III)- and S(reducing bacteria in a sulfate-rich environment. Environ. Microbiol. 8, 141-155.

Kuenen, J. G. (2008). Anammox bacteria: from discovery to application. Nat. Rev. Microbiol. 6, 320-326.

Lebedeva, E. V., Alawi, M., Maixner, F., Jozsa, P.-G., Daims, H., and Spieck, E. (2008). Physiological and phylogenetic characterization of a novel lithoautotrophic nitrite-oxidizing bacterium, 'Candidatus Nitrospira bockiana.' Int. J. Syst. Evol. Microbiol. 58, 242-250.

Lebedeva, E. V., Off, S., Zumbrägel, S., Kruse, M., Shagzhina, A., Lücker, S., Maixner, F., Lipski, A., Daims, H., and Spieck, E. (2011). Isolation and characterization of a moderately thermophilic nitrite-oxidizing bacterium from a geothermal spring. FEMS Microbiol. Ecol. 75, 195-204.
Lefticariu, L., Pratt, L. A., Laverne, J. A., and Schimmelmann, A. (2010). Anoxic pyrite oxidation by water radiolysis products - a potential source of biosustaining energy. Earth Planet. Sci. Lett. 292, 57-67.

Lin, L.-H., James, H., Onstott, T. C., Gihring, T., Lollar, B. S., Boice, E., Pratt, L., Lippmann-Pipke, J., and Bellamy, R. E. S. (2006a). Planktonic microbial communities associated with fracture-derived groundwater in a deep gold mine of South Africa. Geomicrobiol. J. 23, 475-497.

Lin, L.-H., Wang, P.-L., Rumble, D., Lippmann-Pipke, J., Boice, E., Pratt, L. M., Lollar, B. S., Brodie, E. L., Hazen, T. C., Andersen, G. L., Desantis, T. Z., Moser, D. P., Kershaw, D., and Onstott, T. C. (2006b). Longterm sustainability of a high-energy, low-diversity crustal biome. Science 314, 479-482.

Lin, L.-H., Slater, G. F., Sherwood Lollar, B., Lacrampe-Couloume, G., and Onstott, T. C. (2005). The yield and isotopic composition of radiolytic $\mathrm{H}_{2}$, a potential energy source for the deep subsurface biosphere. Geochim. Cosmochim. Acta 69, 893-903.

Lovley, D. R., and Chapelle, F. H. (1995). Deep subsurface microbial processes. Rev. Geophys. 33, 365-381.

Lücker, S., Wagner, M., Roger, A. J., Flax, J. L., Brusseau, G. A., Stahl, D. A., Maixner, F., Pelletier, E., Koch, H., Vacherie, B., Rattei, T., Sinninghe Damsté, J. S., Spieck, E., Le Paslier, D., and Daims, H. (2010). A Nitrospira metagenome illuminates the physiology and evolution of globally important nitrite-oxidizing bacteria. Proc. Natl. Acad. Sci. U.S.A. 107, 13479-13484.

Martens-Habbena, W., Berube, P. M., Urakawa, H., De La Torre, J. R., and Stahl, D. A. (2009). Ammonia oxidation kinetics determine niche separation of nitrifying Archaea and Bacteria. Nature 461, 976-979.

Mayhew, L. E., Swanner, E. D., Martin, A. P., and Templeton, A. S. (2008). Phylogenetic relationships and functional genes: distribution of a gene $(\mathrm{mnxG})$ encoding a putative manganese-oxidizing enzyme in Bacillus species. Appl. Environ. Microbiol. 74, 7265-7271.

Mehta, M. P., Butterfield, D. A., and Baross, J. A. (2003). Phylogenetic diversity of nitrogenase (nifH) genes in deep-sea and hydrothermal vent environments of the Juan de Fuca Ridge. Appl. Environ. Microbiol. 69, 960-970.
Mills, C. T., Amano, Y., Slater, G. F., Dias, R. F., Iwatsuki, T., and Mandernack, K. W. (2010). Microbial carbon cycling in oligotrophic regional aquifers near the Tono Uranium Mine, Japan as inferred from (14 C values of in situ phospholipid fatty acids and carbon sources. Geochim. Cosmochim. Acta 74, 3785-3805.

Moraghan, J. T., and Buresh, R. J. (1977). Chemical reduction of nitrite and nitrous-oxide by ferrous iron. Soil Sci. Soc. Am. J. 41, 47-50.

Moser, D. P., Onstott, T. C., Fredrickson, J. K., Brockman, F. J., Balkwill, D. L., Drake, G. R., Pfiffner, S. M., White, D. C., Takai, K., Pratt, L. M., Fong, J., Lollar, B. S., Slater, G. Phelps, T. J., Spoelstra, N., Deflaun, M., Southam, G., Welty, A. T., Baker, B. J., and Hoek, J. (2003). Temporal shifts in the geochemistry and microbial community structure of an ultradeep mine borehole following isolation. Geomicrobiol. J. 20, 517-548.

Normand, P., and Bouquet, J. (1989). Phylogeny of nitrogenase sequences in Frankia and other nitrogen-fixing microorganisms. J. Mol. Evol. 29, 436-447.

Norton, J. M., Alzerreca, J. J., Suwa, Y., and Klotz, M. G. (2002). Diversity of ammonia monooxygenase operon in autotrophic ammoniaoxidizing bacteria. Arch. Microbiol. 177, 139-149.

Nunoura, T., Hirayama, H., Takami, H. Oida, H., Nishi, S., Shimamura, S., Suzuki, Y., Inagaki, F., Takai, K., Nealson, K. H., and Horikoshi, K. (2005) Genetic and functional properties of uncultivated thermophilic crenarchaeotes from a subsurface gold mine as revealed by analysis of genome fragments. Environ. Microbiol. 7, 1967-1984.

Omoregie, E. O., Mastalerz, V., De Lange, G., Straub, K. L., Kappler, A., Roy, H., Stadnitskaia, A., Foucher, J. -P., and Boetius, A. (2008). Biogeochemistry and community composition of iron- and sulfur-precipitating microbial mats at the Chefren Mud Volcano (Nile Deep Sea Fan, Eastern Mediterranean). Appl. Environ. Microbiol. 74, 3198-3215.

Onstott, T., Lin, L.-H., Davidson, M. Mislowack, B., Borcsik, M., Hall, J., Slater, G., Ward, J., Lollar, B., Lippmann-Pipke, J., Boice, E., Pratt, L., Pfiffner, S., Moser, D., Gihring, T., Kieft, T., Phelps, T., Vanheerden, E., Litthaur, D., Deflaun, M., Rothmel, R., Wanger, G., and Southam, G. (2006). The origin and age of biogeochemical trends in deep fracture water of the Witwatersrand Basin, South Africa. Geomicrobiol. J. 23, 369-414.

Papineau, D. (2006). The Rise of Atmospheric Oxygen and the Evolution of the Sulfur and Nitrogen Cycles on the Archaean and Proterozoic Earth. Ph. D., University of Colorado, Boulder, CO.

Papineau, D., Mojzsis, S. J., Karhu, J. A., and Marty, B. (2005). Nitrogen isotopic composition of ammoniated phyllosilicates: case studies from Precambrian metamorphosed sedimentary rocks. Chem. Geol. 216, 37-58.

Pedersen, K. (1997). Microbial life in deep granitic rock. FEMS Microbiol. Rev. 20, 399-414.

Pedersen, K. (2000). Exploration of deep intraterrestrial microbial life: current perspectives. FEMS Microbiol. Lett. 185, 9-16.

Ploug, H., Musat, N., Adam, B., Moraru, C. L., Lavik, G., Vagner, T., Bergman B., and Kuypers, M. M. M. (2010). Carbon and nitrogen fluxes associated with the cyanobacterium Aphanizomenon sp. in the Baltic Sea. ISME J. 4, 1215-1223.

Rastogi, G., Osman, S. M., Kukkadapu, R., Englehard, M., Vaishampayan, P. A., Andersen, G. L., and Sani, R. K. (2010). Microbial and mineralogical characterizations of soils collected from the deep biosphere of the former Homestake Gold Mine, South Dakota. Microb. Ecol. 60, 539-550.

Reed, S. C., Townsend, A. R., Cleveland, C. C., and Nemergut, D. R. (2010). Microbial community shifts influence patterns in tropical forest nitrogen fixation. Oecologia 164 , 521-531.

Rogers, J. R., and Bennett, P. C. (2004) Mineral stimulation of subsurface microorganisms: release of limiting nutrients from silicates. Chem. Geol. 203, 91-108.

Rogers, J. R., Bennett, P. C., and Choi, W. J. (1998). Feldspars as a source of nutrients for microorganisms. Am. Mineral. 83, 1532-1540.

Rudnick, P., Meletzus, D., Green, A., He, L., and Kennedy, C. (1997). Regulation of nitrogen fixation by ammonium in diazotrophic species of proteobacteria. Soil Biol. Biochem. 29, 831-841.

Sahl, J. W., Schmidt, R., Swanner, E. D., Mandernack, K. W., Templeton, A. S., Kieft, T. L., Smith, R. L., Sanford, W. E., Callaghan, R. L., Mitton, J. B., and Spear, J. R. (2008). Subsurface microbial diversity in deep-graniticfracture water in Colorado. Appl. Environ. Microbiol. 74, 143-152. 
Samarkin, V. A., Madigan, M. T., Bowles, M. W., Casciotti, K. L., Priscu, J. C., Mckay, C. P., and Joye, S. B. (2010). Abiotic nitrous oxide emission from the hypersaline Don Juan Pond in Antarctica. Nat. Geosci 3, 341-344.

Santelli, C. M., Orcutt, B. N., Banning, E., Bach, W., Moyer, C. L., Sogin, M. L., Staudigel, H., and Edwards, K. J. (2008). Abundance and diversity of microbial life in ocean crust. Nature $453,653-656$

Sears, K., Alleman, J. E., Barnard, J. L., and Oleszkiewicz, J. A. (2004). Impacts of reduced sulfur components on active and resting ammonia oxidizers. J. Ind. Microbiol. Biotechnol. 31, 369-378.

Seedorff, E., and Einaudi, M. T. (2004). Henderson porphyry molybdenum system, Colorado: II. Decoupling of introduction and deposition of metals during geochemical evolution of hydrothermal fluids. Econ. Geol. 99, 39-72.

Shelbolina, E., Xu, H., Konishi, H., Kukkadapu, R., Wu, T., and Roden, E. (2010). Microbial oxidation and mineralogical alteration of biotite. Geochim. Cosmochim. Acta 74, A944.

Spang, A., Hatzenpichler, R., BrochierArmanet, C., Rattei, T., Tischler, P., Spieck, E., Streit, W., Stahl, D., Wagner, W., and Schleper, C. (2010). Distinct gene set in two different lineages of ammonia-oxidizing archaea supports the phylum Thaumarchaeota. Trends Microbiol. 18, 331-340.

Spear, J. R., Barton, H. A., Robertson, C. E., Francis, C. A., and Pace, N. R. (2007). Microbial community biofabrics in a geothermal mine adit. Appl. Environ. Microbiol. 73, 6172-6180.

Stamatakis, A., Hoover, P., and Rougemont, J. (2008). A rapid boostrap algorithm for the RAxML web servers. Syst. Biol. 57, 758-771.

Starkenburg, S. R., Chain, P. S. G., Sayavedra-Soto, L. A., Hauser, L., Land, M. L., Larimer, F. W., Malfatti, S. A., Klotz, M. G., Bottomley, P.
J., Arp, D. J., and Hickey, W. J. (2006). Genome sequence of the chemolithoautotrophic nitriteoxidizing bacterium Nitrobacter winogradskyi Nb-255. Appl. Environ. Microbiol. 72, 2050-2063.

Stein, H. J. (1985). A Lead, Strontium and Sulfur Isotope Study of LaramideTertiary Intrusions and Mineralization in the Colorado Mineral Belt with Emphasis on Climax-Type Porphyry Molybdenum Systems Plus a Summary of Other Newly Acquired Isotopic and Rare Earth Element Data. Ph. D., The University of North Carolina, Chapel Hill, NC.

Stein, H. J., and Hannah, J. L. (1985) Movement and origin of ore fluids in climax-type systems. Geology 13, 469-474.

Stevens, T. O., and Mckinley, J. P. (1995). Lithoautotrophic microbial ecosystems in deep basalt aquifers. Science $270,450-455$.

Strauss, E. A., and Lambert, G. A. (2000). Regulation of nitrification in aquatic sediments by organic carbon. Limnol. Oceanogr. 45, 1854-1859.

Swanner, E. D. (2011). MicrobiallyMediated Geochemical Cycling of Iron and Nitrogen within the GraniteHosted Subsurface of Henderson Mine CO. Ph. D., University of Colorado, Boulder, CO.

Takai, K., Moser, D. P., Deflaun, M., Onstott, T. C., and Fredrickson, J. K. (2001). Archaeal diversity in waters from deep South African Gold Mines. Appl. Environ. Microbiol. 67, 5750-5760.

Theobald, P. K. (1965). Preliminary Geologic Map of the Berthoud Pass Quadrangle, Clear Creek and Grand Counties, Colorado. Washington, DC: US Geological Survey.

Treusch, A. H., Kletzin, A., Raddatz, G., Ochsenreiter, T., Quaiser, A., Meurer, G., Schuster, S. C., and Schleper, C. (2004). Characterization of largeinsert DNA libraries from soil for environmental genomic studies of Archaea. Environ. Microbiol. 6, 970-980.
Wankel, S. D., Moisier, A. C., Hansel, C. M., Paytan, A., and Francis, C. A. (2011). Spatial variability in nitrification rates and ammonia-oxidizing microbial communities in the agriculturally impacted Elkhorn Slough Estuary, California. Appl. Environ. Microbiol. 77, 269-280.

Ward, N. L., Challacombe, J. F., Janssen, P. H., Henrissat, B., Coutinho, P. M., Wu, M., Xie, G., Haft, D. H. Sait, M., Badger, J., Barabote, R. D. Bradley, B., Brettin, T. S., Brinkac, L. M., Bruce, D., Creasy, T., Daugherty, S. C., Davidsen, T. M., Deboy, R. T., Detter, J. C., Dodson, R. J., Durkin, A. S., Ganapathy, A., GwinnGiglio, M., Han, C. S., Khouri, H., Kiss, H., Kothari, S. P., Madupu, R., Nelson, K. E., Nelson, W. C., Paulsen, I., Penn, K., Ren, Q., Rosovitz, M. J., Selengut, J. D., Shrivastava, S., Sullivan, S. A., Tapia, R. Thompson, L. S., Watkins, K. L., Yang, Q., Yu, C., Zafar, N., Zhou, L., and Kuske, C. R. (2009). Three genomes from the phylum Acidobacteria provide insight into the lifestyles of these microorganisms in soils. Appl. Environ. Microbiol. 75 2046-2056.

Watson, S. W., Bock, E., Valois, F. W., Waterbury, J. B., and Schlosser, U. (1986). Nitrospira marina gen. nov. sp. nov.: a chemolithotrophic nitriteoxidizing bacterium. Arch. Microbiol. 144, 1-7.

Weidler, G. W., DornmayrPfaffenhuemer, M., Gerbl, F. W., Heinen, W., and Stan-Lotter, H. (2007). Communitites of Archaea and Bacteria in a subsurface radioactive thermal spring in the Austrian Central Alps, and evidence of ammonia-oxidizing Crenarchaeota. Appl. Environ. Microbiol. 73, 259-270.

Wu, L., Beard, B. L., Roden, E. E. and Johnson, C. M. (2009). Influence of $\mathrm{pH}$ and dissolved $\mathrm{Si}$ on $\mathrm{Fe}$ isotope fractionation during dissimilatory microbial reduction of hematite. Geochim. Cosmochim. Acto 73, 5584-5599.
Wu, L., Jacobson, A. D., and Hausner, M. (2008). Characterization of elemental release during microbe-granite interactions at $\mathrm{T}=28^{\circ} \mathrm{C}$. Geochim. Cosmochim. Acta 72, 1076-1095.

Young, J. P. W. (2005). "The phylogeny and evolution of nitrogenases," in Genomes and Genomics of Nitrogenfixing organisms, eds R. Palacios and W. E. Newton (Dordrecht: Springer), 221-241.

Zhang, C. L., Ye, Q., Huang, Z., Li, W., Chen, J., Song, Z., Zhao, W., Bagwell, C., Inskeep, W. P., Ross, C., Gao, L., Wiegel, J., Romanek, C. S., Shock, E. L., and Hedlund, B. P. (2008). Global occurrence of archaeal amoA genes in terrestrial hot springs. Appl. Environ. Microbiol. 74, 6417-6426.

Zhao, W., Song, Z., Jiang, H., Li, W., Mou, X., Romanek, C. S., Wiegel, J., Dong, H., and Zhang, C. L. (2011). Ammonia-oxidizing Archaea in Kamchatka Hot Springs. Geomicrobiol. J. 28, 149-159.

Conflict of Interest Statement: The authors declare that the research was conducted in the absence of any commercial or financial relationships that could be construed as a potential conflict of interest.

Received: 29 August 2011; accepted: 01 December 2011; published online: 20 December 2011.

Citation: Swanner ED and Templeton AS (2011) Potential for nitrogen fixation and nitrification in the granite-hosted subsurface at Henderson Mine, CO. Front. Microbio. 2:254. doi: 10.3389/fmicb.2011.00254

This article was submitted to Frontiers in Extreme Microbiology, a specialty of Frontiers in Microbiology.

Copyright $\odot 2011$ Swanner and Templeton. This is an open-access article distributed under the terms of the Creative Commons Attribution Non Commercial License, which permits non-commercial use, distribution, and reproduction in other forums, provided the original authors and source are credited. 